\title{
Online Learning as Policy to Increasing the Quality of Education Based on 4.0 Era in Sultan Ageng Tirtayasa University
}

\author{
Syihabudin ${ }^{1}$, Rangga Galura Gumelar ${ }^{2}$ \\ \{ syihabudin@untirta.ac.id.com ${ }^{1}$, rangga.gumelar@untirta.ac.id ${ }^{2}$ \} \\ 1,2 University of Sultan Ageng Tirtayasa, Banten, Indonesia
}

\begin{abstract}
Industrial Revolution 4.0 era had an impact on changes the perspective in higher education especially to adjust what the industry needs. Entering the era disruptive or industrial revolution 4.0, Untirta tried to make a breakthrough of the goverment by developing the curriculum based on online learning. It has been determined by Rector Policy No. 22019 regarding Online Learning Organizations in Sultan Ageng Tirtayasa. This policy will be apllying for all subject study, but for the beginning, it will be apply for General Courses Subject (MKU) first, where at least maximum $70 \%$ will be held ind online learning. However these system still used the quality standards of higher education's Untirta. Based on qualitative approach, it was found that the lecturer were ready and agree, that the online learning had a positive effect on the development of education in Untirta. The problem that must be immediately addressed is, to increase the ability of lecturers to innovate, especially transfering materials study using animations or by interesting subject, in this case understanding of instructional communication becomes an important part that must be considered. Spada's system give the big space for discussion and also it can be able to provide an explanation and to increase the intensity communication and teamwork between the lecturer and the students. The suggestion from this study is, the guidelines and quality standars for online learning should be established as an indicator to measure the effectiveness of the successful online learning in Untirta.
\end{abstract}

Keywords: Olnline Learning, Untirta, Quality of Education, Instructional Communication, Revolution of Industry Era 4.0.

\section{Introduction}

It's not easy to discuss about quality of higher education in Indonesia. Continual improvement in the quality of education is a must, that's why universities should be produce the freshgraduate, those who are ready to fight and have the quality. The available work share can be fought over with outsiders. Will we only passive and silent with this condition? Surely, this stituaton can be a challenge for Sultan Ageng Tirtayasa University (Untirta), to be better and make something new. Untirta was achieved the accreditation of the institution with Predicate in 2019, where previously in six study programs in Untirta was awarded accreditation with A. This situation would be a trigger for other study programs to achieve the best accreditation. This is in line with [1] where specifically explained in Chapter III Quality Assurance which consists of Quality Assurance System, Higher Education Standards, Accreditation, Higher Education Database and Higher Education Service Institutions. Strengthening of the Internal Quality Assurance System (SPMI) and the External Quality Assurance System (SPME) is absolute and very important in university, which aims to 
improve the quality of education in higher national education. In accordance with the provisions [2] that higher education national standards (SN Dikti) are divided into National Education Standards, National Research Standards and National Community Service Standards which are the minimum standards that must be met by universities in Indonesia. As for higher education standards, given the independence to develop standards beyond higher education national standards (SN Dikti). This is what actually became an opportunity as well as a challenge for Untirta to be able to develop and exceed the national standard of higher education in accordance with [3] article 4, paragraph 4.

The implementation of SPMI Untirta divided into at least 8 educational standards, 8 research standards, 8 service standards and 4 additional university standards, where if combined all of them there are 28 standards that must be fulfilled in the course of quality in Untirta. The Institute of Educational Development and Quality Assurance (LP3M) Untirta, has the duty to oversee the quality of the existing process in Untirta, in accordance with the provisions and standards set by the University. In this case LP3M has the right to conduct monitoring and evaluation of the implementation of SPMI at the University, Faculty and Study Program level. In fact, with the latest nine criteria issued by the National Accreditation Board for Higher Education (BAN PT), the accreditation of strengthening the SPMI becomes the entrance as the most important part in implementing the quality process in Higher Education. In line with that, the accreditation of both Institutions and Study Programs whose names have been changed are no longer using the alphabet but rather as Superior, Very Good, Good and Enough, clearly illustrating how the process of this quality, is not something that can be bargained again. To be able to achieve superior predicate, it has been stated that the quality in Higher Education must exceed the standards set by the Government through the (Permenristekdikti) in the national standards of higher education.

Entering the era of disruptive or so-called industrial revolution 4.0, Untirta tried to make a breakthrough in accordance with the provisions of the government by developing an education curriculum based on online learning. This policy [4] will be apllying for all subject study, but for the beginning it will be apply fot General Courses Subject (MKU) first, wherea at least maximum $70 \%$ will be held ind online learning. Later this online learning policy will not only apply to MKU courses but also to other courses. In this study, the researcher tries to see how is the readiness of Untirta conducting this online learning? How are the challenges and obstacles experienced by Untirta in this case especially the lecturers and staff on the implementation of this Online learning?

\section{Literature review}

\section{Online Learning}

The defining E-Learning at this time, not only based on computers alone, but this learning system absolutely must have an internet network in its application [5]. There is a fundamental difference between online and conventional learning, these online learning can be said to be more flexible, it means that process in the teaching and learning of students and lecturers no need to be in the classroom, but it can be agreed upon how then the material is given [6]. The task of lecturers in tridharma education, which is not only in terms of teaching but is required to carry out research and service to society, often its clashes with the task of teaching. Beside that, for the lecturers who have additional assignments, also have problems in terms of accuracy in teaching hours. That's why, the implementation of this online learning, provides good benefits so that later students are not left behind in the material in accordance with the Learning Outcomes that have been targeted. In other things,should be an intention, that in 
online learning, the lecturers must be able to provide explanations and facilities for students to be able to understand the subject presented as well as by adding illustrations, pictures, videos, photos and even journals or examples research [7].

In this context, it is indeed necessary to deepen the abilities, especially for the lecturers, how then they prepare themselves to be able to process and make videos or animations to facilitate teaching in their lecture. It is important not to forget that in the implementation of elearning, communication must be established between students and their lecturers. The consequence that will be change in the lerning system, which consists of: 1) Curriculum and Character Education, 2) Learning Maaterials based on technology, information and communication, 3) Entrepreneurship, 4) Alignment, and 5) Evaluation [8].

\section{Education Based on 4.0}

The 4.0-based education criteria are inseparable from the history and development of the Industry which began in phase 1.0 with the presence of mechanized production, then phase 2.0 with mass production and standardization, 3.0 was marked by automation and robots and 4.0 related to the Cyber Physical System which was marked by digitalization in industry [9]. It further [10] provides four design concepts from industry 4.0 principles; namely 1) Interconnection is a way that facilitates communication with the interconnection of all available devices, censors for workers who can communicate through the internet network; 2) Information Transparency, which discusses all data summarized in a digital data; 3) Technical Assistance, namely as part of a system that facilitates and supports humans in solving and solving existing problems; 4) Decentralized decision, namely on Improvement. In the era of the industrial revolution 4.0, the development of human qualities especially in the mastery of information technology is needed. This is highly correlated with how universities collect from high must be competitive and in accordance with current industry needs.

With these conditions, the industrial era 4.0 will give the impact on learning systems to be changed in Higher Education right now. In this case teh curriculm of Higher Education must be able to create in the direction of innovation and the ability of students with the criteria needed in this 4.0 era. If the universities late to respond it, or produce graduates who are not in accordance with current market needs, it's almost certain that there will be an increase in unemployment in Indonesia. Although it must be recognized at this time, there is still little confusion about the differences between vocational and non-vocational universities, because in the end almost all universities pursue the readiness of their graduates to compete and be accepted in the workforce. Apart from that, that the industrial world prefers how someone who is prepared practically is not just at the theoretical level.

\section{Instructional Communication}

The learning process between lecturers and students is very closely related to how the communication patterns developed by them. Instructional communication is a communication activity developed to be understood using a series of methods including communication and information technology [11]. The study process in class, which is usually rigid, or tends to be one-way, with the presence of online learning is expected to further more flexible and two way direction communicaton. The students, can be active to be able to interact and active in asking or discussing in the forums that have been provided. 


\section{Research methods}

This study uses a qualitative approach with a case study method in which the object is General Courses Subject lecturers, who conduct online learning. This approach is very suitable for analysis and study of the theme of this study as stated [12] that research related to qualitative is more likely to ask the direction of the process rather than the results. The research was carried out in the Untirta LP3M, where the researcher can be an object of active passivation research, which is incorporated with research subjects in the framework of implementing online learning preparation. Key informants in this study were determined by purposive sampling, which is divided into informants engaged in quality assurance, namely the head of Untirta LP3M, then the lecturers who carry out online learning, as well as the IT team or Spada Untitra who carry out these online learning activities. Observations, in-depth interviews and literature studies that refer to the implementation of the quality standards of education in Indonesia, become important instruments conducted by researchers of this research.

\section{Results and Discussion}

The Untirta Educational Development and Quality Assurance Institute (LP3M) was formed in June 2012 as a refinement and improvement of the institutional status previously preceded by the establishment of the Quality Assurance Unit (UPM) in 2009, based on the Rector's Decree Number: 331 / H43 / KP / SK / 2009 which has the task to plan and implement a quality assurance system both in the field of education, research and service at the University as a whole. This institution is directly under the coordination of the rector. In the implementation of this quality assurance, LP3M has coordinated with the Quality Assurance at the Faculty Level or known as the Faculty Quality Assurance Group. With the existence of these cross faculties, coordination related to the quality process, especially in the teaching and learning process, can be controlled and evaluated as part of improving the quality of education. One of the online learning was the implementation of an ad-Hoc team between LP3M and the Spada team. This aims to synchronize the guidelines and technical assistance with LP3M, so that the quality of the online implementation process is maintained in accordance with established standards. 


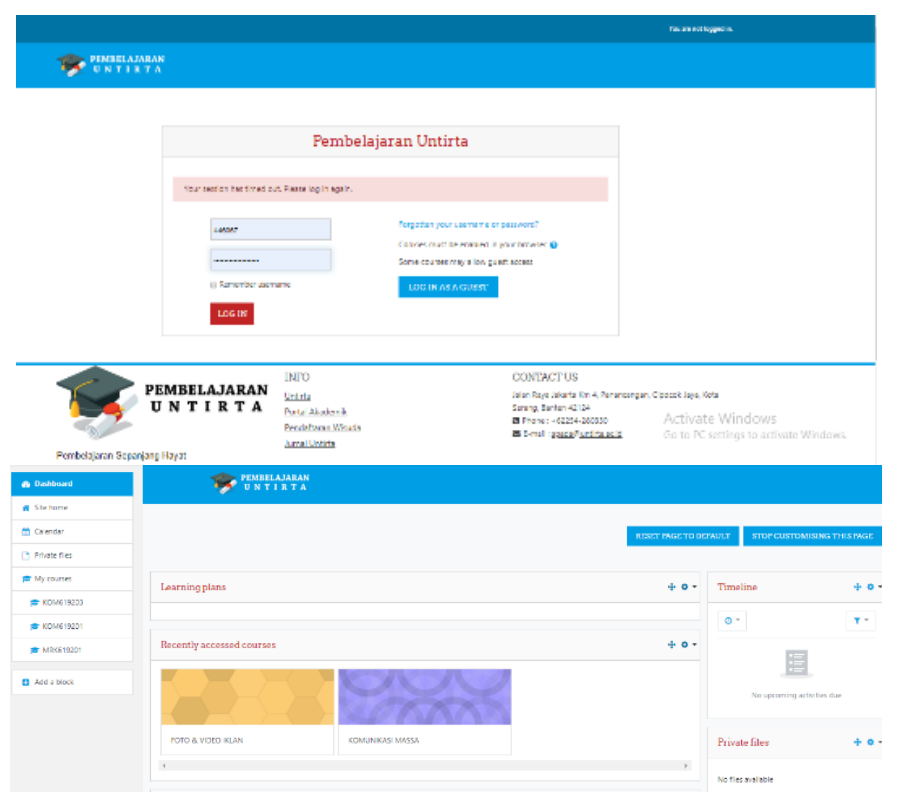

Fig 1. Display Spada Untirta

The several criteria or items in the research results show that:

\section{Preparation Stage}

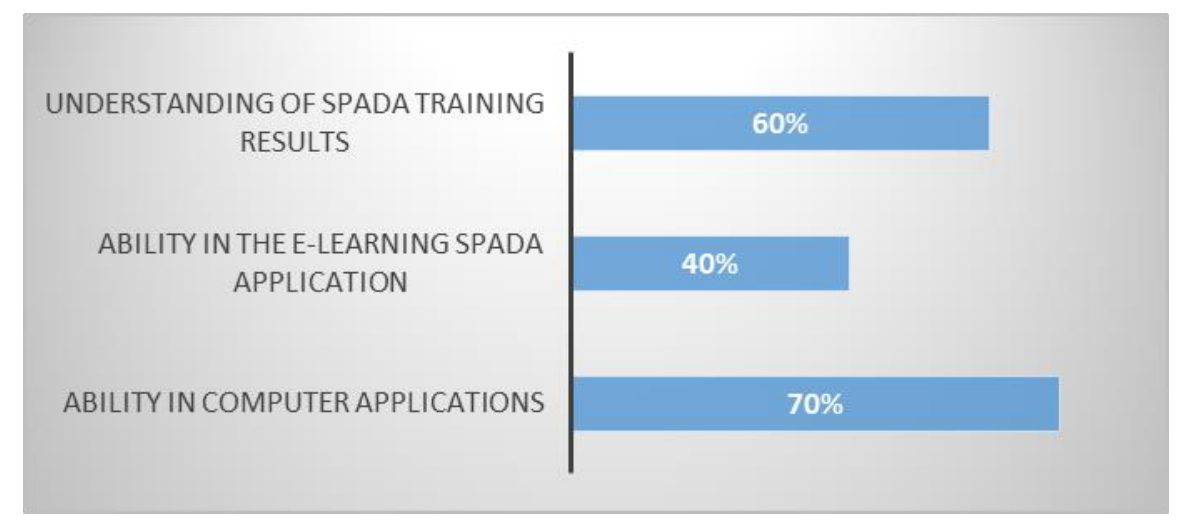

Fig 2. Overview of Spada Understanding

The implementation of this online learning, began with Spada Untirta team, where they were tasked with preparing matters relating to the preparation of the lecturers in carrying out this online learning, as well as creating an account for each lecturer so that they could then use the account in their teaching. In this account,MKU lecturers are given an explanation of how they input data, store data and then interact with students. In this account, lecturers can save all files starting from lecture materials, assignments and even discussion forums with students. Based on these preparatory observations, there are still obstacles that the lecturers who carry 
out this lecture do not know how to optimize their existing accounts. There are still lecturers who still have problems use of computer technology.

\section{Learning Materials}

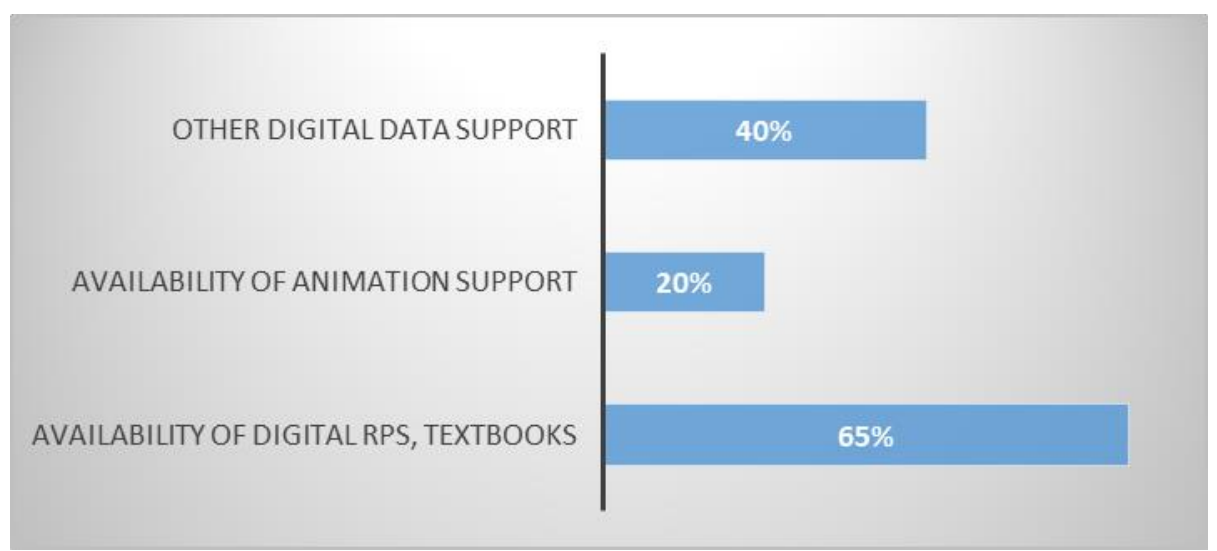

Fig 3. Overview of Digital Data Mastery

For the initial trial of this online learning implementation, it was conducted on MKU lecturers. The lecturers in this online learning ure are asked to later provide more innovative and more interesting material to students. The policy is for MKU lecturers to submit material in the form of video. The lecturers are taken pictures and video and then uploaded, which is it can use the youtube link or directly on the account of each of the lecturers at Spada Untirta. The weakness found it regarding of the Supporting material, how to support and understanding of animation or anything that helps to facilitate understanding for students. Impact it's still difficult for the lecturers ,because their background was not directly related with this program.

\section{Role of SPADA Untirta}

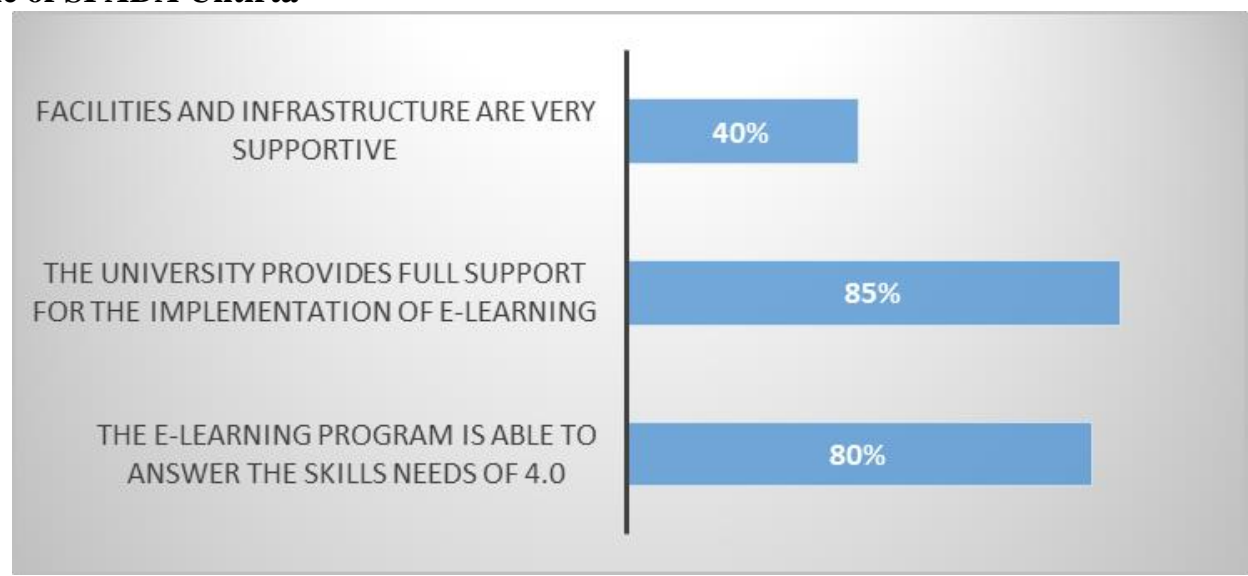

Figu 4. Contributions of the Untirta Spada 
The creativity and management of these online learning, starting with the giving of each Spada account lecturer, later the students who take this course, will be abble to chat or get the metaerial form the lecturer. The role of the Spada Untirta team is very helpful for lecturers to understand how the application of this system. Apart from that the lecturers feel how support from the University in the implementation of e-learning is included support of information technology tools that are needed in supporting the implementation of online learning, though It must be recognized that compliance with the standard facilities and infrastructure in this online system is still ongoing and gradual.

\section{Conclusions and suggestions}

The application of this online learning, can almost said, no problem to be applied by lecturers who are assisted by education staff. But it does require readiness and maturity in its implementation. Limitations on facilities and infrastructure, development of lecturers' abilities, lack of training for lecturers are still an obstacle that must be major concern. The pattern of equality of perception of what actually online learning is must be clear, not then online learning is only used as a transfer from conventional study like face to face, to lectures recorded on video (youtube). This is very important, so online learning as part of anticipation in the 4.0 era, become an important part and can be used for its designation.

Suggestions in this study are 1) Deepening or more training especially for lecturers in developing lecture content especially in developing instructional communication; 2) To do the planning and determination of quality standards as an indicator and evaluation material for the implementation of online learning in Untirta; 3) The established policy must be supported by all elements of Untita's academic community.

\section{References}

[1] Undang-Undang No.12 Tahun 2012 tentang Pendidikan Tinggi

[2] Permenristekdikti No. 44 Tahun 2015 tentang Standar Nasional Pendidikan Tinggi

[3] Permenristekdikti No. 62 Tahun 2016 tentang Sistem Penjaminan Mutu Pendidikan Tinggi (SPM Dikti)

[4] Peraturan Rektor Nomor 2 Tahun 2019 tentag Penyelenggaraan Pembelajaran Daring (Online) di Lingkungan Universitas Sultan Ageng Tirtayasa

[5] Munir. : Kurikulum Berbasis Teknologi Informasi Dan Komunikasi. Bandung, Alfabeta (2010).

[6] Allan J. Henderson. : The E-learning Question and Answer Book.USA, Amacom (2003)

[7] Clark, Ruth Colvin \& Richard E. Mayer. : E-learning and the Science of Instruction. Third Edition. San Francisco, Pfeiffer (2011).

[8] Muhammad Yahya. : Era Industri 4.0: Tantangan dan Peluang Perkembangan Pendidikan Kejuruan Indonesi. Disampaikan pada pidaro Pengukuhan Guru Besar Fakultas Tehnik Universitas Makassar Bidang Ilmu Pendidikan Kejuruan (2018).

[9] Hermann, M., Pentek, T., \& Otto, B. : Design Principles for Industrie 4.0 Scenarios. Presented at the 49th Hawaiian International Conference on Systems Science (2016).

[10] Irianto, D. : Industry 4.0; The Challenges of Tomorrow. Disampaikan pada Seminar Nasional Teknik Industri, Batu-Malang (2017).

[11] Pawit M. Yusu. : Komunikasi Instruksional Teori dan Praktik, Jakarta, PT. Bumi Aksara (2010).

[12] Yin, R.K. : Case study reasearch: Design \& methods. California, Sage Publications, Inc. (2013). 